\title{
Predicting Energy Requirement for Cooling the Building Using Artificial Neural Network
}

\author{
Rajesh Kumar ${ }^{1}$, R.K. Aggarwal, ${ }^{2,}$, J.D. Sharma ${ }^{1}$ and Sunil Pathania ${ }^{3}$ \\ ${ }^{1}$ Department of Physics, Shoolini University, Bajhol, Solan (HP) 173 212, India \\ ${ }^{2}$ Department of Environmental Science, Dr Y S Parmar University of Horticulture \& Forestry, Nauni (Solan), \\ 173230, India \\ ${ }^{3}$ Department of Engineering \& Technology, Shoolini University, Bajhol, Solan (HP), India
}

\begin{abstract}
This paper explores total cooling load during summers and total carbon emissions of a six storey building by using artificial neural network (ANN). Parameters used for the calculation were conduction losses, ventilation losses, solar heat gain and internal gain. The standard back-propagation learning algorithm has been used in the network. The energy performance in buildings is influenced by many factors, such as ambient weather conditions, building structure and characteristics, the operation of sub-level components like lighting and HVAC systems, occupancy and their behavior. This complex situation makes it very difficult to accurately implement the prediction of building energy consumption. The calculated cooling load was 0.87 million $\mathrm{kW}$ per year. ANN application showed that data was best fit for the regression coefficient of 0.9955 with best validation performance of 0.41231 in case of conduction losses. To meet out this energy demand various fuel options are presented along with their cost and carbon emission.
\end{abstract}

Keywords: Energy requirement, heat gain, ventilation losses, conduction losses, carbon emission, regression coefficient.

\section{INTRODUCTION}

Himachal Pradesh is located in north India with Latitude $30^{\circ} 22^{\prime} 40^{\prime \prime} \mathrm{N}$ to $33^{\circ} 12^{\prime} 40^{\prime \prime} \mathrm{N}$, Longitude $75^{\circ}$ $45^{\prime} 55^{\prime \prime} \mathrm{E}$ to $79^{\circ} 04^{\prime} 20^{\prime \prime} \mathrm{E}$, height (From mean sea Level) 350 meter to 6975 meter and average rainfall $1469 \mathrm{~mm}$. For our study we have taken a building in Solan district which is located between the longitudes 76.42 and 77.20 degree and latitudes 30.05 and 31.15 degree north the elevation of the district ranges from 300 to 3,000 meter above sea level. During six month's summers (April to September) people use electricity (provided on subsidized rates) and other conventional fuels (diesel/petrol) to lower down the temperature. These result in burden on already depleting conventional fuels and same time causing emission of $\mathrm{CO}_{2}$ and global warming. The other option to meet out energy requirement is solar passive technologies. This requires measured data of solar radiation which is not available in the state. This can be estimated by using various models on the basis of sunshine hour or temperature. The mean hourly values of such data for various places in India are available in the handbook by Mani [1]. The major problem is to calculate the energy demand of a building during summers. ANNs are the most widely used artificial intelligence models in the application of building energy prediction. In the past

*Address corresponding to this author at the Department of Environmental Science, Dr Y S Parmar University of Horticulture \& Forestry, Nauni (Solan), 173230, India; Tel: +911792252023; Fax: +911792252279;

E-mail: rajeev1792@rediffmail.com twenty years, researchers have applied ANNs to analyze various types of building energy consumption in a variety of conditions, such as heating/cooling load, electricity consumption, sub-level components operation and optimization, estimation of usage parameters. In 2006, Kalogirou [2] did a brief review of the ANNs in energy applications in buildings, including solar water heating systems, solar radiation, wind speed, air flow distribution inside a room, prediction of energy consumption, indoor air temperature, and HVAC system analysis. In [3], Yokoyama et al. used a back propagation neural network to predict cooling demand in a building. In their work, a global optimization method called modal trimming method was proposed for identifying model parameters. Kreider et al. [4] reported results of a recurrent neural network on hourly energy consumption data to predict building heating and cooling energy needs in the future, knowing only the weather and time stamp. Based on the same recurrent neural network, Ben-Nakhi and Mahmoud [5] predicted the cooling load of three office buildings. Considering the influence of weather on the energy consumption in different regions, Yan and Yao [6] used a back propagation neural network to predict building's heating and cooling load in different climate zones represented by heating degree day and cooling degree day. The neural network was trained with these two energy measurements as parts of input variables. In the application of building electricity usage prediction, an early study [7] has successfully used 
neural networks for predicting hourly electricity consumption as well as chilled and hot water for an engineering center building. Nizami and Al-Garni [8] tried a simple feed-forward neural network to relate the electric energy consumption to the number of occupancy and weather data. Wong et al. [9] used a neural network to predict energy consumption for office buildings with day-lighting controls in subtropical climates. The outputs of the model include daily electricity usage for cooling, heating, electric lighting and total building. Hou et al. [10] predicted airconditioning load in a building, which is a key to the optimal control of the HVAC system. Lee et al. [11] used a general regression neural network to detect and diagnose faults in a building's air-handling unit. Aydinalp et al. [12] showed that the neural network can be used to estimate appliance, lighting and space cooling energy consumption and it is also a good model to estimate the effects of the socio-economic factors on this consumption in the Canadian residential sector. Gouda et al. [13] used a multi-layered feedforward neural network to predict internal temperature with easily measurable inputs which include outdoor temperature, solar irradiance, heating valve position and the building indoor temperature. Kreider et al. [4] reported results of recurrent neural networks on hourly energy consumption data. Karatasou et al. [14] studied how statistical procedures can improve neural network models in the prediction of hourly energy loads. Azadeh et al. [15] showed that the neural network was very applicable to the annual electricity consumption prediction in manufacturing industries where energy consumption has high fluctuation. It is superior to the conventional non-linear regression model through Analysis of Variance (ANOVA). We have taken a university building having six storey which works for seven hours during a day time. The dimensions are length $45 \mathrm{~m}, 15 \mathrm{~m}$ wide and $18 \mathrm{~m}$ in height.

\section{METHOD AND MATERIAL}

Under the steady state approach (which does not account the effect of heat capacity of building materials), the heat balance for room air can be written as [16]:

$Q_{\text {total }}=Q_{c}+Q_{s}+Q_{i}+Q_{v}$

where

$Q_{\text {total }}$ is total energy requirement if it is -ve then heating is required and if it is +ve then cooling is required.
$Q_{c}$ is conduction losses in a building
$Q_{S}$ is solar gain in a building
$Q_{i}$ is internal gain in a building
$Q_{v}$ is ventilation losses in a building

\section{Conduction}

The rate of heat conduction $\left(Q_{c}\right)$ through any element such as roof, wall or floor under steady state can be written as

$Q_{c}=A U \Delta T$

where
$A=$ surface area $\left(\mathrm{m}^{2}\right)$
$\mathrm{U}=$ thermal transmittance $\left(\mathrm{W} / \mathrm{m}^{2} \mathrm{~K}\right)$
$\Delta T=$ temperature difference between inside and outside air (K)

If the surface is also exposed to solar radiation then

$\Delta T=T_{\text {so }}-T_{i}$

where $T_{i}$ is the indoor temperature; $T_{\text {so }}$ is the solar air temperature, calculated using the expression:

$T_{\text {so }}=T_{0}+\alpha S_{T} / h_{0}-\varepsilon \Delta R / h_{0}$

where

$\mathrm{T}_{0}=$ daily average value of hourly ambient temperature $(\mathrm{K})$

$\alpha=$ absorptance of the surface for solar radiation

$\mathrm{S}_{\mathrm{T}}=$ daily average value of hourly solar radiation incident on the surface $\left(\mathrm{W} / \mathrm{m}^{2}\right)$

$h_{0}=$ outside heat transfer coefficient $\left(W / m_{2} K\right)$

$\varepsilon=$ emissivity of the surface

$\Delta \mathrm{R}=$ difference between the long wavelength radiation incident on the surface from the sky and the surroundings, and the radiation emitted by a black body at ambient temperature

\section{Solar Heat Gain}

The solar gain through transparent elements can be written as: 
Table 1: Heat Production Rate in a Human Body

\begin{tabular}{|c|c|c|}
\hline \multirow{2}{*}{ Activity } & \multicolumn{2}{|c|}{ Rate of heat production } \\
\cline { 2 - 3 } & (W) & 35 \\
\hline \hline Sleeping & 60 & 45 \\
\hline Resting & 80 & 55 \\
\hline Sitting, Normal office work & 100 & 85 \\
\hline Typing & 150 & 110 \\
\hline Slow walking (3 km/h) & 200 & 140 \\
\hline Fast walking (6 km/h) & 250 & More than 170 \\
\hline
\end{tabular}

$Q_{s}=\alpha_{s} \Sigma A_{i} S_{g i} T_{i}$

where

$\alpha_{\mathrm{s}}=$ mean absorptivity of the space

$A_{i}=$ area of the ith transparent element $\left(m^{2}\right)$

$\mathrm{S}_{\mathrm{gi}}=$ daily average value of solar radiation (including the effect of shading) on the ith transparent element $\left(\mathrm{W} / \mathrm{m}^{2}\right)$

$\mathrm{T}_{\mathrm{i}}=$ transmissivity of the ith transparent element

$M=$ number of transparent elements

\section{Ventilation}

The heat flow rate due to ventilation of air between the interior of a building and the outside depends on the rate of air exchange. It is given by:

$Q_{V}=\rho V_{r} C \Delta T$

where,

$\rho=$ density of air $\left(\mathrm{kg} / \mathrm{m}^{3}\right)$

$V_{r}=$ ventilation rate $\left(\mathrm{m}^{3} / \mathrm{s}\right)$

$C=$ specific heat of air $(\mathrm{J} / \mathrm{kgK})$

$\Delta \mathrm{T}=$ temperature difference $(\mathrm{To}-\mathrm{Ti})(\mathrm{K})$

\section{Internal Gain}

The heat generated by occupants is a heat gain for the building; its magnitude depends on the level of activity of a person. Table 1 shows the heat output rate of human bodies for various activities [17].

The total rate of energy emission by electric lamps is also taken as internal heat gain. Table 2 shows the heat gain due to appliances (televisions, refrigerators, etc.) should also be added to the Qi [17].

Table 2: Wattage of Common Household Appliances

\begin{tabular}{|c|c|}
\hline Equipment & Load (in W) \\
\hline \hline Television & 400 \\
\hline Refrigerator & 120 \\
\hline Coffee Machine & 400 \\
\hline Computer & 150 \\
\hline Ceiling Fan & 200 \\
\hline Air Conditioner & 2500 \\
\hline
\end{tabular}

$\mathrm{Qi}=($ No of people $\times$ heat output rate $)+$ Rated wattage of lamps + Appliance load

Following data was used in the present study.

The overall heat transfer coefficients for window, door and walls are [18]:

$\mathrm{U}_{\text {glazing }}=5.7 \mathrm{~W} / \mathrm{m}^{2} \mathrm{~K}$

$\mathrm{U}_{\text {wall }}=3 \mathrm{~W} / \mathrm{m}^{2} \mathrm{~K}$

$U_{\text {roof }}=2.3 \mathrm{~W} / \mathrm{m}^{2} \mathrm{~K}$

Daily average outside temperature throughout year $=24.9^{\circ} \mathrm{C}$

Outside heat transfer coefficient is $22.7 \mathrm{~W} / \mathrm{m}^{2} \mathrm{~K}$

Inside design temperature was $19 \stackrel{\circ}{\circ}$

Mean absorptivity of the space is 0.6

Transmissivity of window is 0.8

Density of air is $1.2 \mathrm{~kg} / \mathrm{m}^{3}$

Specific heat of air is $1005 \mathrm{~J} / \mathrm{kg} \mathrm{K}$ 
Table 3: Conduction Losses

\begin{tabular}{|c|c|c|c|c|c|}
\hline Wall Exposed to Sun & Material & $U\left(W / m^{2} K\right)$ & $A\left(m^{2}\right)$ & $\mathbf{T}_{\text {so }}$ & $Q_{c}(\ln k W)$ \\
\hline South wall & Brick Masonry & 3 & 630.1 & 22.3 & 4.8 \\
\hline North wall & Brick Masonry & 3 & 746.0 & 19.2 & 2.0 \\
\hline West wall & Brick Masonry & 3 & 224.0 & 22.3 & 0.5 \\
\hline East wall & Brick Masonry & 3 & 196.0 & 22 & 1.5 \\
\hline Roof & Tin & 3.2 & 518.0 & 25.8 & 6.5 \\
\hline Glazing & Glass & 5.7 & 386.5 & 22.3 & 7.3 \\
\hline \multicolumn{5}{|c|}{ Total conduction losses per annum } & 97632 \\
\hline
\end{tabular}

Mean hourly values of data shown in Table 3 for various places in India are available in the handbook by Mani [1].

\section{RESULTS}

The total conduction losses in a building are calculated as Table 3.
$\mathrm{Q}_{\mathrm{c}}=22.6 \mathrm{~kW}=97632 \mathrm{~kW}$ per annum whose ANN graphs are shown in Figures $\mathbf{1}$ and $\mathbf{2}$.

The total solar gain in a building is calculated as Table 4.

$\mathrm{Q}_{\mathrm{s}}=67.4 \mathrm{~kW}=84924 \mathrm{~kW}$ per annum whose ANN graphs are shown in Figures 3 and 4.

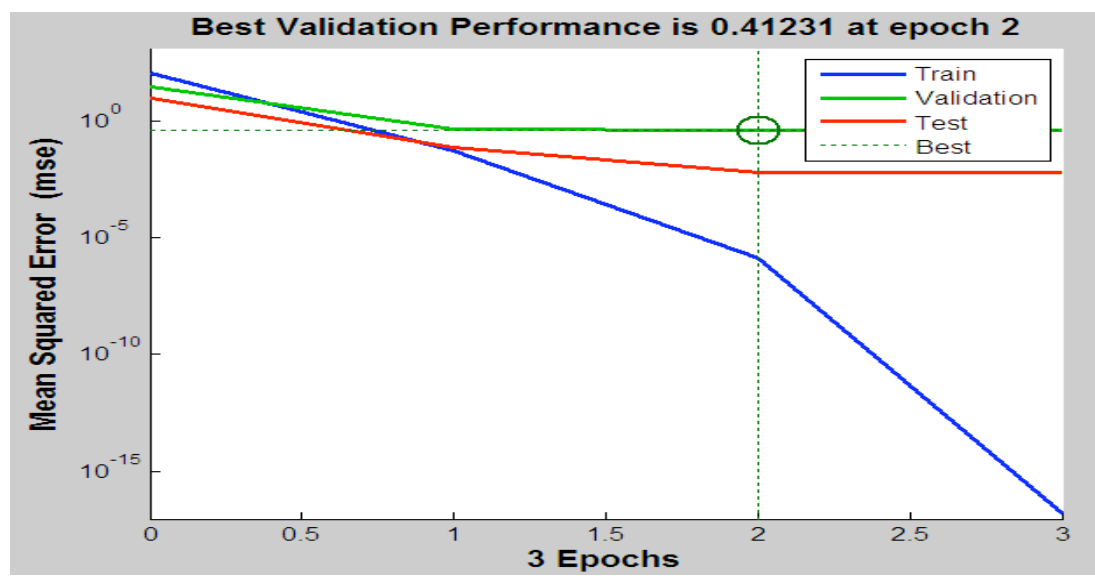

Figure 1: Validation Performance of Conduction Losses $\left(Q_{c}\right)$.

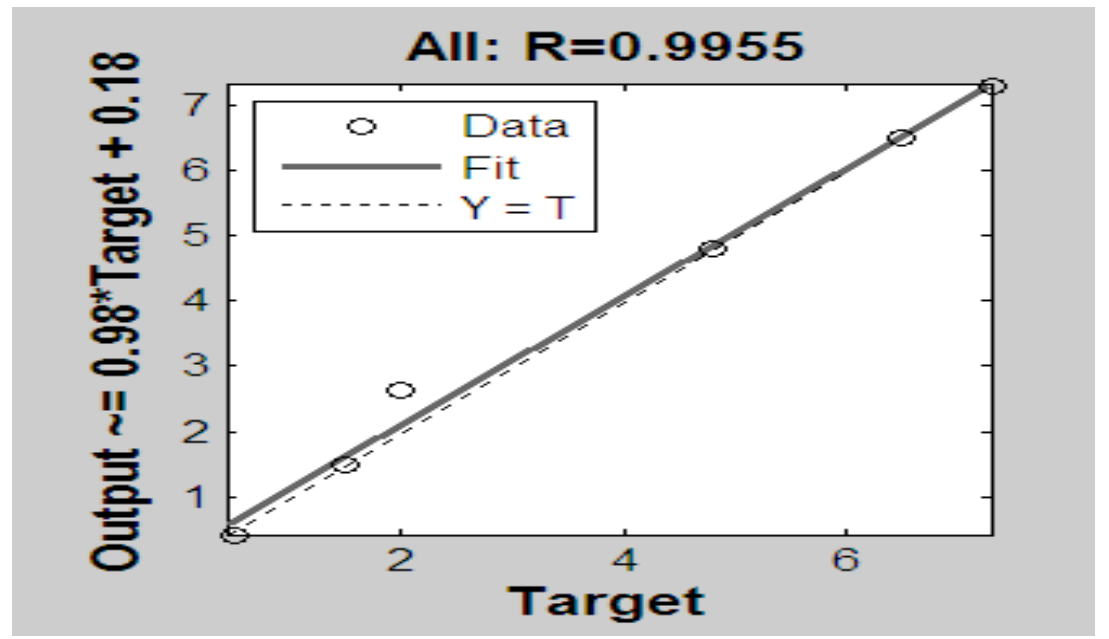

Figure 2: Regression Analysis of Conduction Losses $\left(\mathrm{Q}_{\mathrm{c}}\right)$. 
Table 4: Heat Gain

\begin{tabular}{|c|c|c|c|}
\hline Wall Exposed to Sun & $\mathbf{A}(\mathbf{l n} \mathbf{m})$ & $\mathbf{S}_{\mathbf{g}}\left(\mathbf{W} / \mathbf{m}^{2}\right)$ & $\mathbf{Q}_{\mathbf{s}}(\mathbf{l n} \mathbf{k W})$ \\
\hline \hline South wall & 206.0 & 202.4 & 12.5 \\
\hline North wall & 89.7 & 109.7 & 3.1 \\
\hline West wall & 54.4 & 107.2 & 1.8 \\
\hline East wall & 36.4 & 264.8 & 50.0 \\
\hline Roof & 518 & & 84924 \\
\hline
\end{tabular}

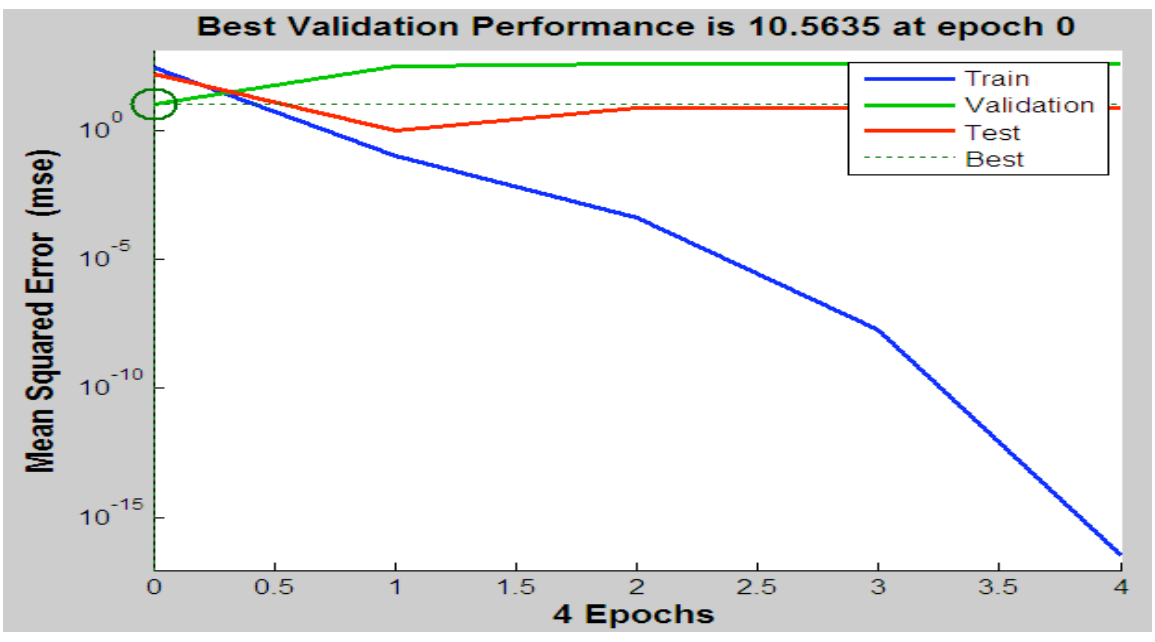

Figure 3: Validation Performance of Heat Gain $\left(Q_{s}\right)$.

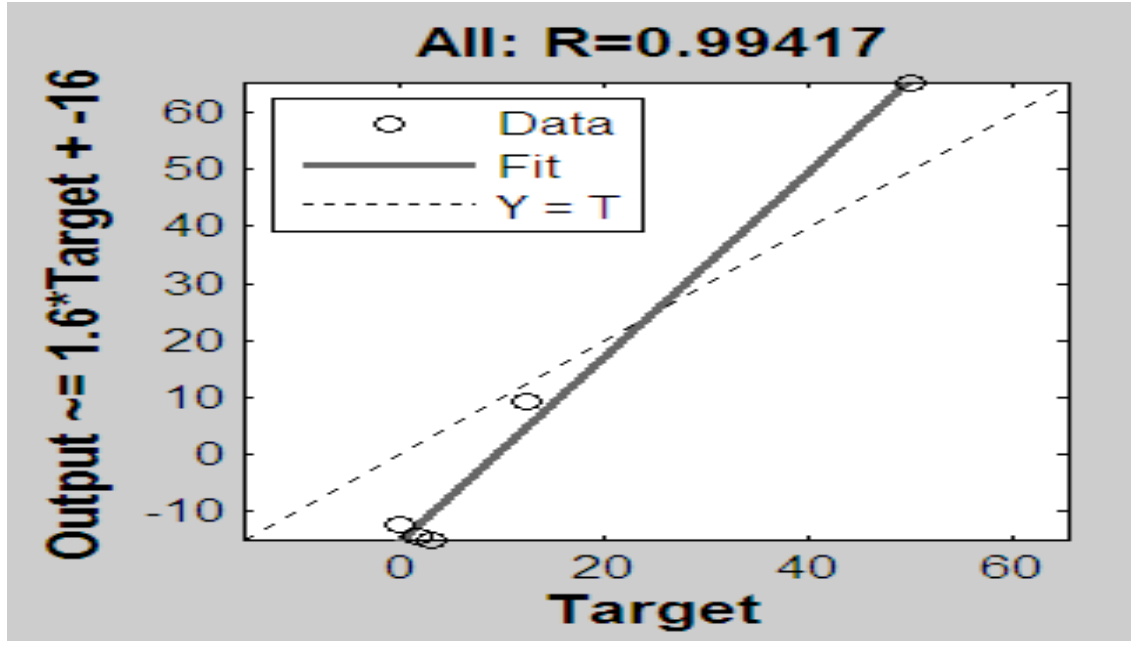

Figure 4: Regression Analysis of Heat Gain $\left(Q_{S}\right)$.

The total ventilation losses in a building are calculated as Table 5 .

$\mathrm{Q}_{\mathrm{v}}=136.1 \mathrm{~kW}=587952 \mathrm{~kW}$ per annum whose ANN graphs are shown in Figures 5 and 6.

The total internal gain in a building is calculated as Table 6.
$Q_{i}=108.5 \mathrm{~kW}=104160 \mathrm{~kW}$ per annum whose ANN graphs are shown in Figures 7 and 8.

The total energy requirement during winter is calculated as Table 7.

$$
\mathrm{Q}_{\mathrm{m}}=97632+84924+587952+104160=874668
$$
$\mathrm{kW}$ per annum whose ANN graphs are shown in Figures 9 and 10. 
Table 5: Ventilation Losses

\begin{tabular}{|c|c|c|c|c|}
\hline Wall & Density of air $\left(\mathbf{i n ~} \mathbf{~ g} / \mathbf{m}^{\mathbf{3}}\right)$ & Specific heat of air (in J/kg K) & Temperature & $\mathbf{Q}_{\mathbf{v}}(\mathbf{I n} \mathbf{~ k W})$ \\
\hline \hline South & 1.2 & 1005 & 3.3 & 0.2 \\
\hline North & 1.2 & 1005 & 3.3 & 27.1 \\
\hline West & 1.2 & 1005 & 3 & 24.1 \\
\hline East & 1.2 & 1005 & 6.8 & 55.7 \\
\hline Roof & 1.2 & 1005 & 587952 \\
\hline
\end{tabular}

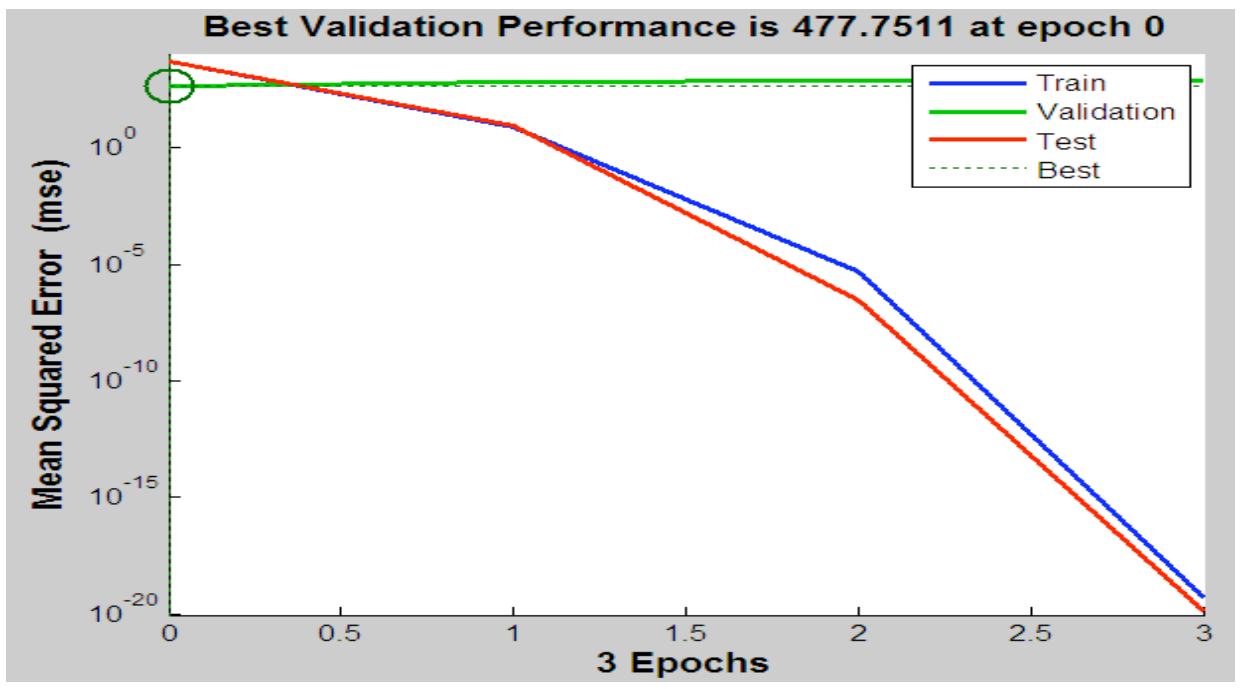

Figure 5: Validation Performance of Ventilation Losses $\left(Q_{v}\right)$.

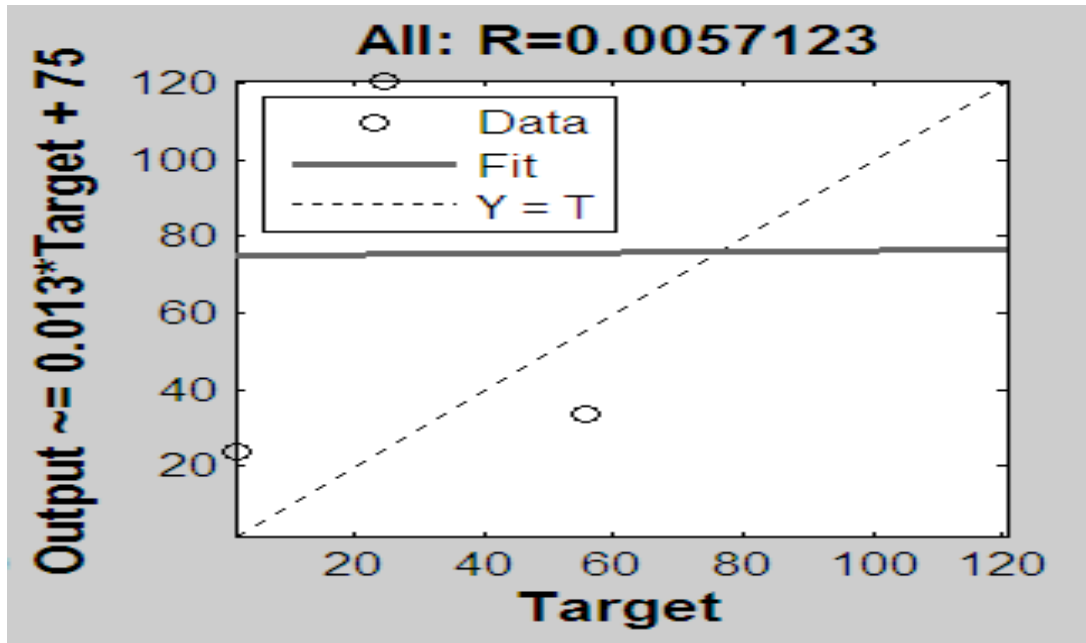

Figure 6: Regression Analysis of Ventilation Losses $\left(Q_{v}\right)$.

\section{DISCUSSION}

The neural network model was used with 10 hidden neurons. Figures 1, 3, 5, 7 and 9 didn't indicate any major problem with the training. The validation and test curves were very similar. The evaluation and validation of an artificial neural network prediction model were based upon one or more selected error metrics.
Generally, neural network models which perform a function approximation task will use a continuous error metric such as mean absolute error (MAE), mean squared error (MSE) or root mean squared error (RMSE). The errors will be summed over the validation set of inputs and outputs, and then normalized by the size of the validation set [19]. Here we had used mean 
Table 6: Internal Heat Gain

\begin{tabular}{|c|c|c|c|c|c|c|c|}
\hline Floors & Occupants & Tube Lights & Bulbs & Fan & $\begin{array}{c}\text { AC } \\
\text { (1.5 ton each) }\end{array}$ & Others & $Q_{i}($ in $k W)$ \\
\hline Ground & 18 & 43 & 2 & 15 & 2 & $\begin{array}{c}\text { Television=1 } \\
\text { Computer }=15 \\
\text { Refrigerator }=1\end{array}$ & 17.9 \\
\hline First & 35 & 57 & 3 & 16 & 4 & $\begin{array}{c}\text { Computer=66 } \\
\text { Refrigerator=1 } \\
\text { Instument=2 }\end{array}$ & 24.0 \\
\hline Second & 110 & 62 & 3 & 12 & 2 & $\begin{array}{c}\text { Television=1 } \\
\text { Computer=2 } \\
\text { Refrigerator=1 } \\
\text { Instrument=4 }\end{array}$ & 27.7 \\
\hline Fifth & 6 & 8 & - & 14 & - & - & 3.7 \\
\hline \multicolumn{7}{|c|}{ Total internal heat gain per annum } & 104160 \\
\hline
\end{tabular}

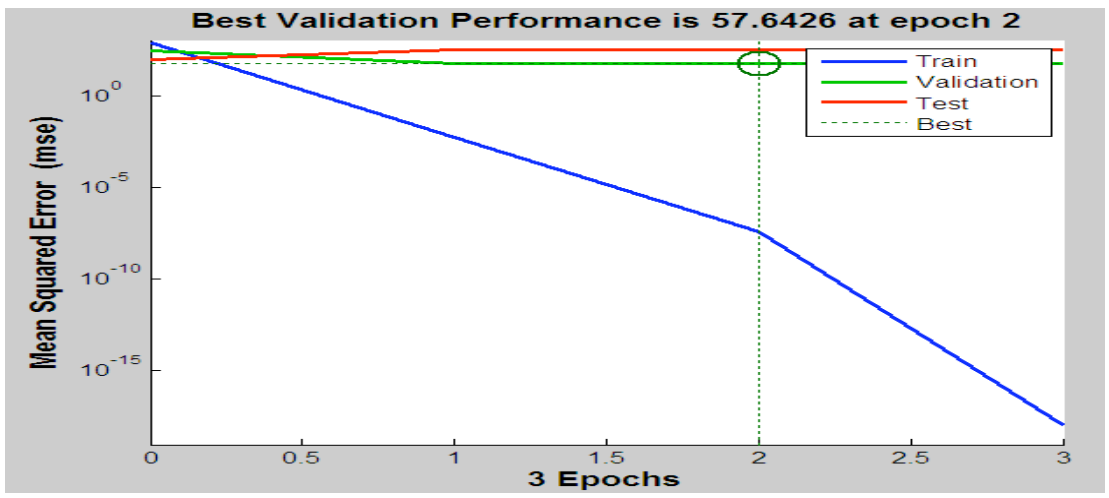

Figure 7: Validation Performance of Internal Heat Gain $\left(Q_{i}\right)$.

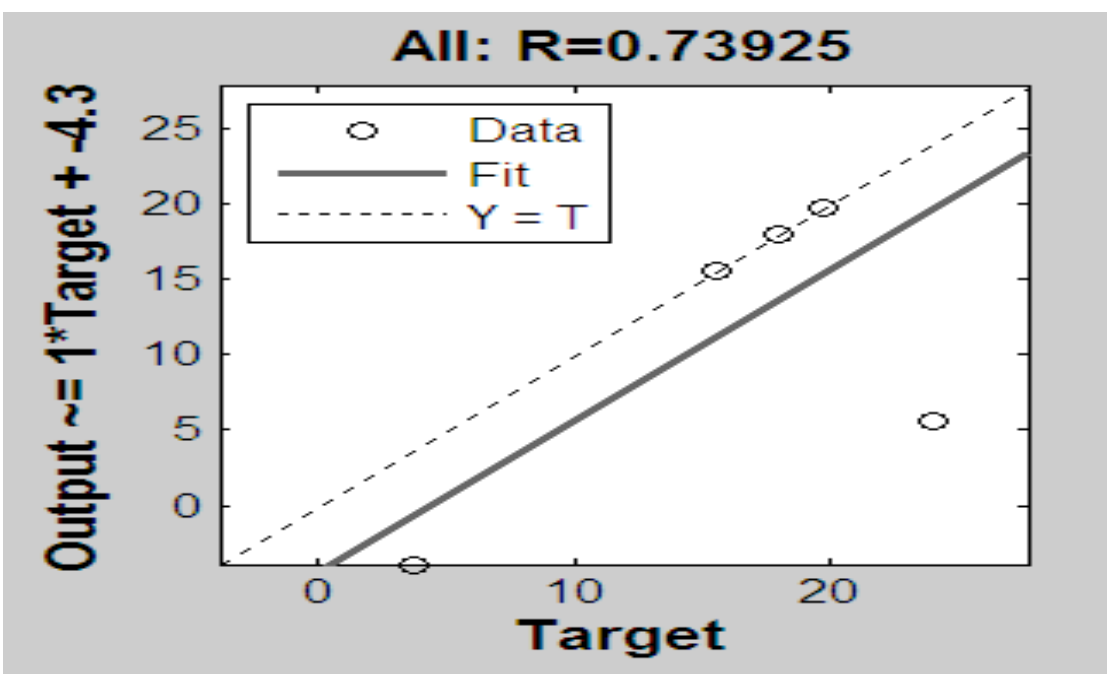

Figure 8: Regression Analysis of Internal Heat Gain $\left(Q_{i}\right)$. 
Table 7: Total Heat Load in kW

\begin{tabular}{|c|c|c|c|c|c|}
\hline & $\mathbf{Q}_{\mathbf{c}}$ & $\mathbf{Q}_{\mathbf{s}}$ & $\mathbf{Q}_{\mathbf{v}}$ & $\mathbf{Q}_{\mathbf{i}}$ & $\mathbf{Q}_{\mathbf{m}}$ \\
\hline \hline & 22.6 & 67.4 & 136.1 & 108.5 & 334.6 \\
\hline Annual value & 97632 & 84924 & 587952 & 104160 & 874668 \\
\hline
\end{tabular}

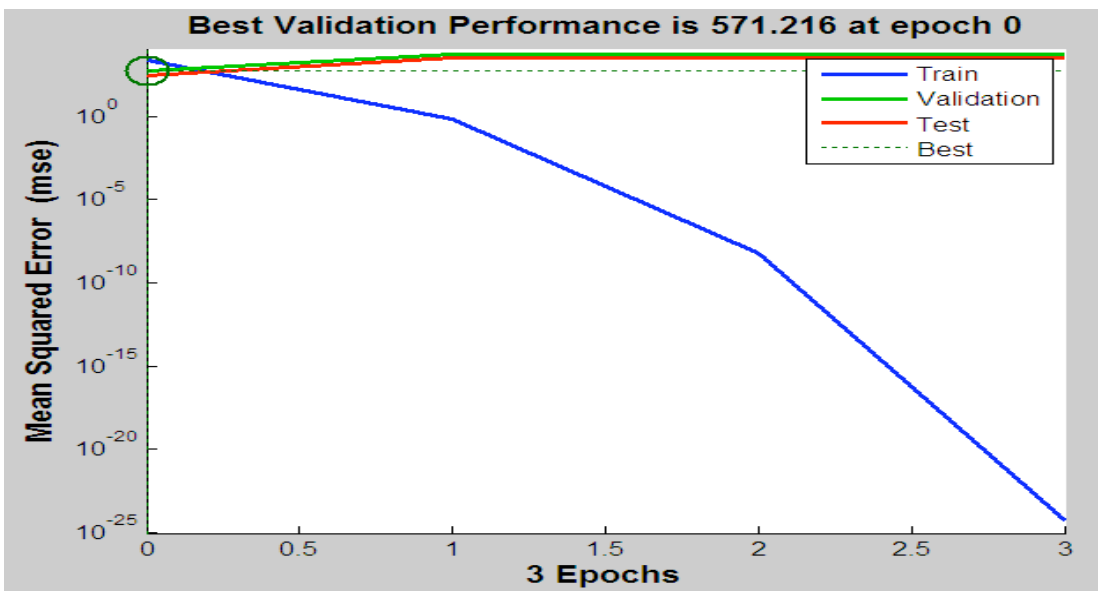

Figure 9: Validation Performance of Heat Load $\left(\mathrm{Q}_{\mathrm{m}}\right)$.

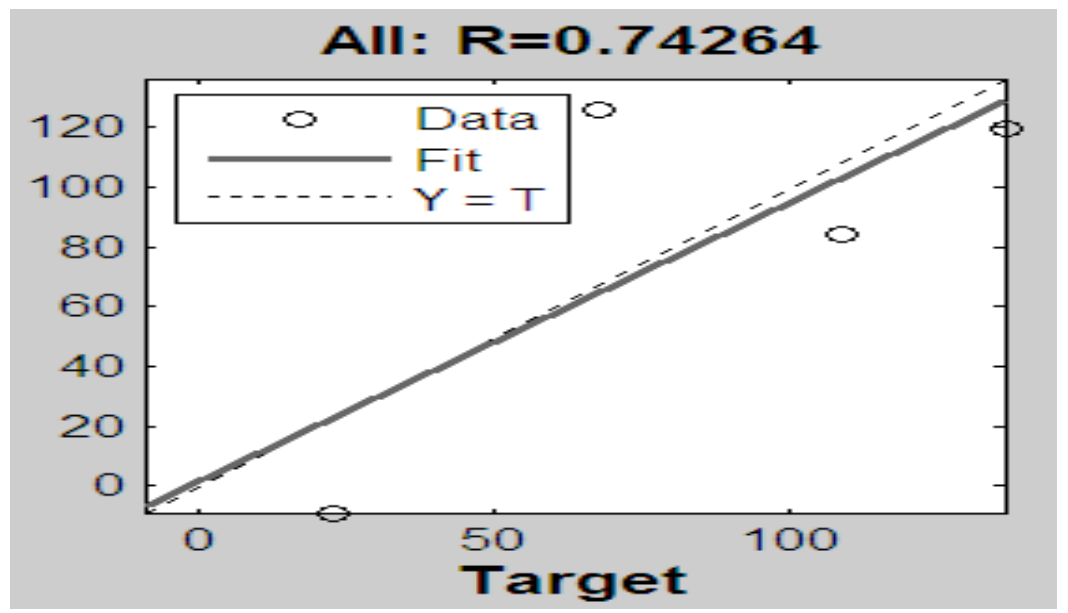

Figure 10: Regression Analysis of Heat load $\left(Q_{m}\right)$.

squared error (MSE) for the best validation performance. The next step in validating the network was to create a regression plot, which showed the relationship between the outputs of the network and the targets. If the training were perfect, the network outputs and the targets would be exactly equal, but the relationship was rarely perfect in practice. The result was shown in the Figures 2, 4, 6, 8 and 10. The three axes represented the training, validation and testing data. The dashed line in each axis represented the perfect result - outputs $=$ targets. The solid line represented the best fit linear regression line between outputs and targets. The $R$ value was an indication of the relationship between the outputs and targets. If $R=$ 1 , this indicated that there was an exact linear relationship between outputs and targets. If $R$ was close to zero, then there was no linear relationship between outputs and targets.

\section{CONCLUSIONS}

The study reveals that the total cooling load of a six storey building is 0.87 million $\mathrm{kW}$ thus, cooling is required to meet out this energy demand. If we use electricity it will produce 3.5 ton carbon per annum and the cost of electricity used will be $\$ 47,709.16$ as depicted in Table 8.

If we use diesel to meet out this energy requirement then 236.2 ton of carbon will be emitted and it will cost 
Table 8: Carbon Emission and Cost

\begin{tabular}{|c|c|c|c|c|}
\hline Fuel & Carbon Emission per kWh (in g) & $\begin{array}{c}\text { Total Carbon Emission } \\
\text { (in kg) }\end{array}$ & $\begin{array}{c}\text { Fuel Required } \\
\text { (in USD) }\end{array}$ & \begin{tabular}{c} 
Total cost \\
\hline \hline Electricity
\end{tabular} \\
\hline Diesel & 4 & $3,498.7$ & $67,709.16$ \\
\hline Solar Energy & 0 & $2,36,160.4$ & 0 & $57,250.96$ \\
\hline
\end{tabular}

$\$ 57,250.9$. The above results necessitate the use of solar passive technologies to meet out this energy requirement during summers.

\section{REFERENCES}

[1] Mani A, Rangarajan S. Solar radiation over India, Allied Publishers, New Delhi 1982.

[2] Kalogirou SA. Artificial neural networks in energy applications in buildings. Int J Low-Carbon Technol 2006; 1(3): 201-16. http://dx.doi.org/10.1093/ijlct/1.3.201

[3] Yokoyama R, Wakui $T$, Satake R. Prediction of energy demands using neural network with model identification by global optimization. Energy Conver Manag 2009; 50(2): 31927. http://dx.doi.org/10.1016/j.enconman.2008.09.017

[4] Kreider JK, Claridge DE, Curtiss P, Dodier R, Haberl JS, Krarti $M$. Building energy use prediction and system identification using recurrent neural networks. J Solar Energy Eng 1995; 117(3): 161-6. http://dx.doi.org/10.1115/1.2847757

[5] Ben-Nakhi AE, Mahmoud MA. Cooling load prediction for buildings using general regression neural network. Energy Conver Manag 2004; 45(13-14): 2127-41.

http://dx.doi.org/10.1016/j.enconman.2003.10.009

[6] Yan CW, Yao J. Application of ANN for the prediction of building energy consumption at different climate zones with HDD and CDD. In: Proceedings of the 2nd International Conference on Future Computer and Communication 2010; 3: 286-9.

[7] Joint Center for Energy Management (JCEM). Final report: Artificial neural net-works applied to loan STAR data. Tech Rep 1992; TR/92/15.

[8] Javeed Nizami S, Al-Garni AZ. Forecasting electric energy consumption using neural networks. Energy Policy 1995; 23(12): 1097-104.

http://dx.doi.org/10.1016/0301-4215(95)00116-6

[9] Wong SL, Wan KKW, Lam TNT. Artificial neural networks for energy analysis of office buildings with day lighting. Appl Energy 2010; 87(2): 551-7.

http://dx.doi.org/10.1016/j.apenergy.2009.06.028
[10] Hou Z, Lian Z, Yao Y, Yuan X. Cooling-load prediction by the combination of rough set theory and an artificial neuralnetwork based on data fusion technique. Appl Energy 2006; 83(9): 1033-46.

http://dx.doi.org/10.1016/j.apenergy.2005.08.006

[11] Lee WY, House JM, Kyong NH. Subsystem level fault diagnosis of a building's air-handling unit using general regression neural networks. Appl Energy 2004; 77(2): 15370.

http://dx.doi.org/10.1016/S0306-2619(03)00107-7

[12] Aydinalp M, Ugursal VI, Fung AS. Modeling of the appliance, lighting, and space-cooling energy consumptions in the residential sector using neural networks. Appl Energy 2002; 71(2): 87-10.

http://dx.doi.org/10.1016/S0306-2619(01)00049-6

[13] Gouda MM, Danaher S, Underwood CP. Application of an artificial neural network for modeling the thermal dynamics of a building's space and its heating system, Mathematical and Computer Modeling of Dynamical Systems: Methods. Tools Appl Eng Related Sci 2002; 8(3): 333-44.

[14] Karatasou S, Santamouris M, Geros V. Modeling and predicting building's energy use with artificial neural networks: methods and results. Energy Buildings 2006; 38(8): 949-58.

http://dx.doi.org/10.1016/j.enbuild.2005.11.005

[15] Azadeh A, Ghaderi S, Sohrabkhani S. Annual electricity consumption forecasting by neural network in high energy consuming industrial sectors. Energy Conver Manag 2008; 49(8): 2272-8.

http://dx.doi.org/10.1016/i.enconman.2008.01.035

[16] Nayak JK, Prajapati JA. Handbook on Energy Conscious Buildings, Prepared under the interactive $R$ \& $D$ project no. 3/4(03)/99-SEC between Indian Institute of Technology, Bombay and Solar Energy Centre, Ministry of Nonconventional Energy Sources, Government of India, May 2006.

[17] Bansal NK, Hauser G, Minke G. Passive building design, Elsevier Science, New York 1994.

[18] SP: 41 (S\&T)- Handbook on functional requirements of buildings, Bureau of Indian Standards, New Delhi 1987.

[19] Kartam N, Flood I, Garrett J. Fundamentals and Applications from ASCE Press 1996. 